Fols View/Frint Document Cover Sheet tok

This document was retrieved from the Documentation and Records Manaqement (DRM) ISEARCH System. It is intended for Information only and may not be the most recent or updated version. Contact a Document Service Center (see Hanford Info for locations) if you need additional retrieval information.

Accession \#: D196022524

Document \#: SD-W058-QAPP-001

Title/Desc:

PROJECT SPECIFIC QA PLAN PROJECT W-058 REPLACEMENT CROSS SITE TRANSFER SYSTEM

Pages: 16 


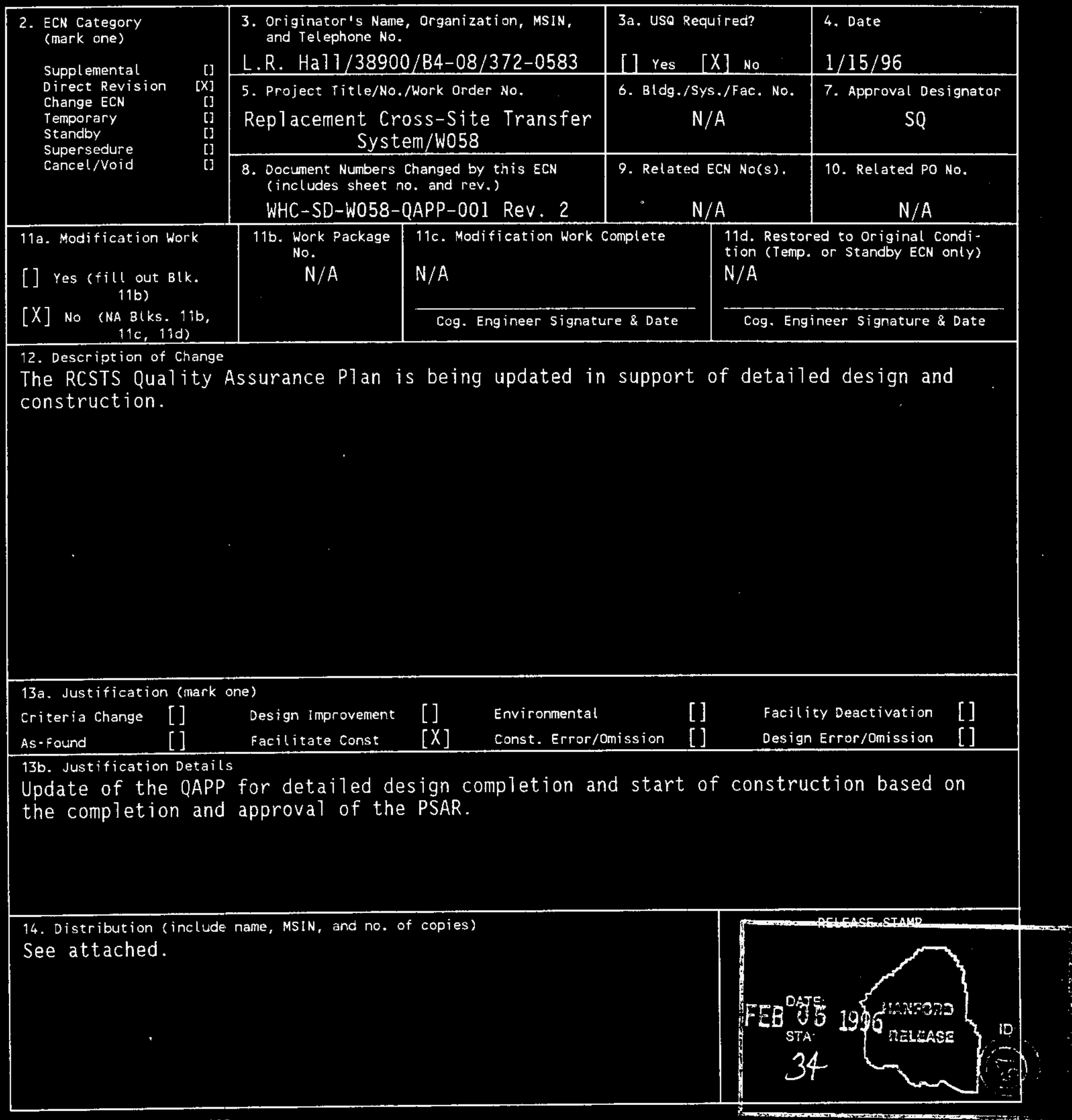




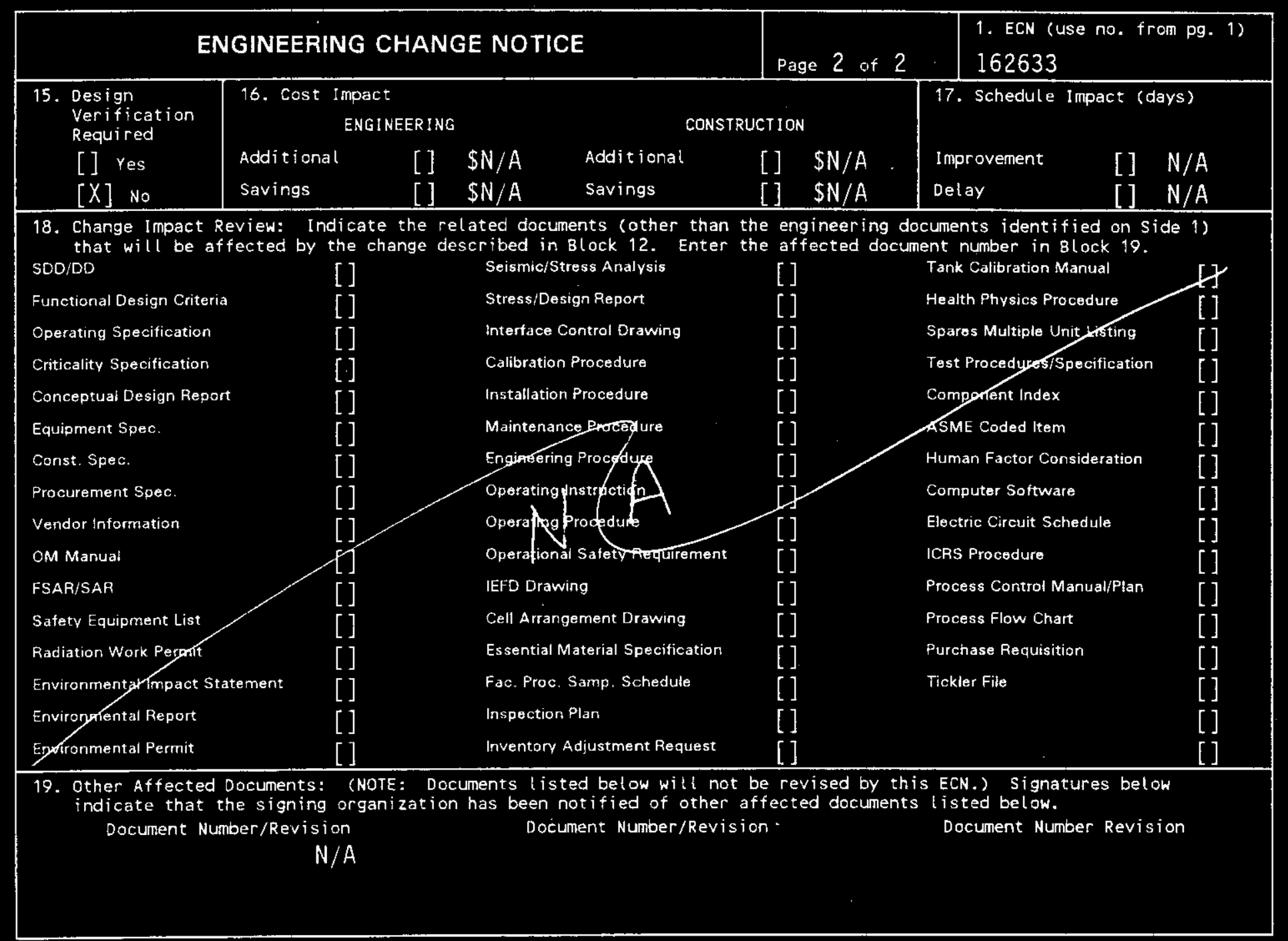

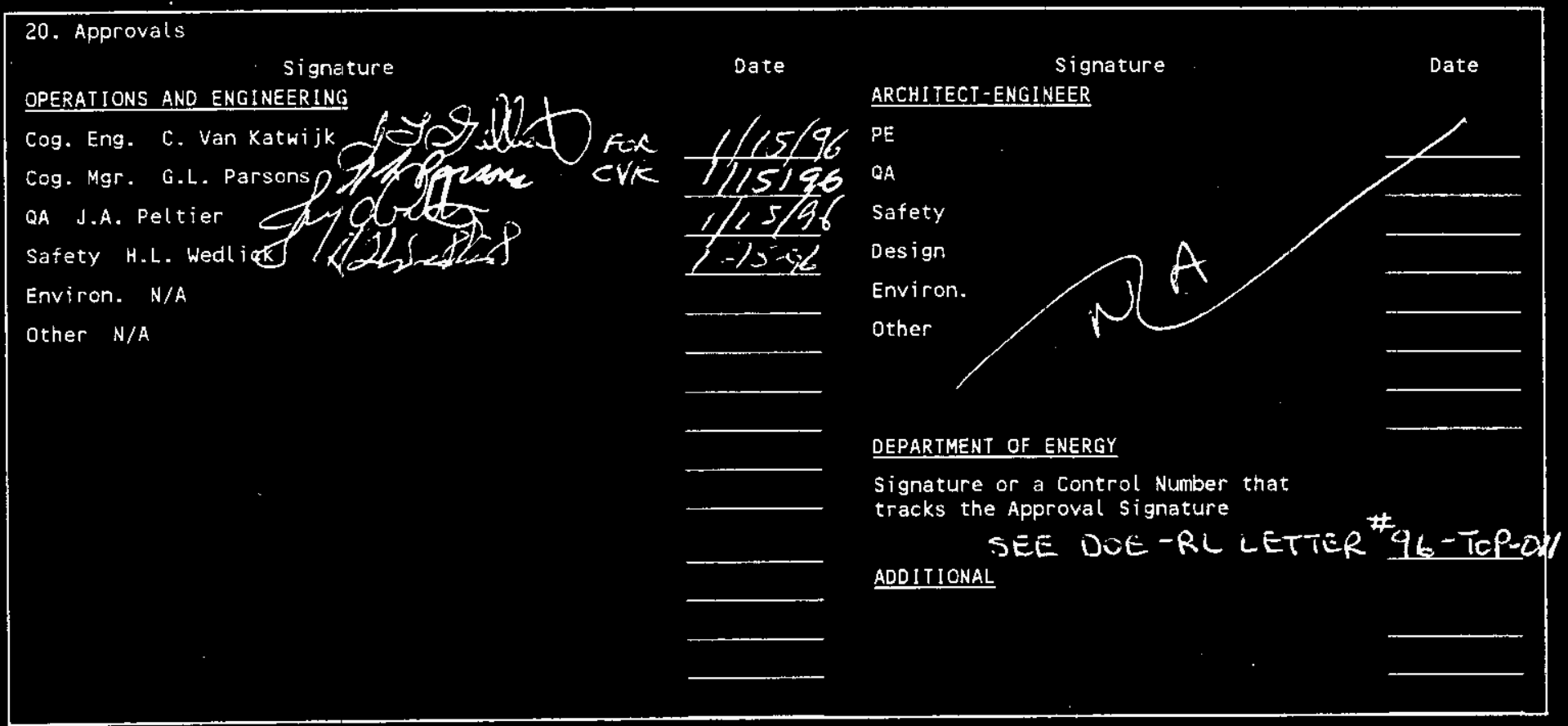




\section{PROJECT SPECIFIC QUALITY ASSURANCE PLAN PROJECT W-058 REPLACEMENT CROSS-SITE TRANSFER SYSTEM}

LANNY R. HALL

WHC, Richland, WA 99352

U.S. Department of Energy Contract DE-AC06-87RLI0930

EDT/ECN: 162633

UC: 2030

Org Code: 38900

Charge Code: N58LH

B\&R Code: 39EW31301

Total Pages: 11

Key Words: RCSTS, Quality Assurance Program Plan, W058,

Abstract: Project Specific Quality Assurance Program Plan for project W058, Replacement Cross-Site Transfer System Project.

TRADEMARK DISCLAIMER. Reference herein to any specific commercial product, process, or service by trade name, trademark, manufacturer, or otherwise, does not necessarily constitute or imply its endorsement, recommendation, or favoring by the United States Government or any agency thereof or its contractors or subcontractors.

Printed in the United States of America. To obtain copies of this document, contact: WHC/BCS Document Control Services, P.0. Box 1970, Mailstop H6-08, Rishand WA.99352, Phone (509) 372-2420; Fax (509) 376-4989.
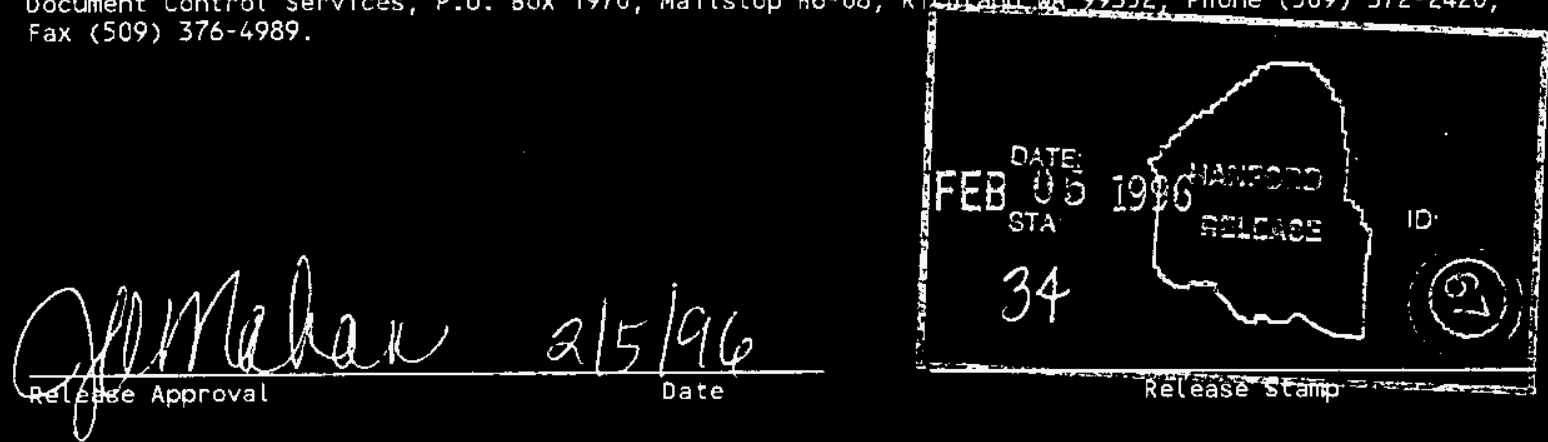

Approved for Public Release 


\section{RECORD OF REVISION}

$$
\begin{aligned}
& \text { (1) Document Number } \\
& \text { WHC-SD-W058-QAPP- } \\
& 001
\end{aligned}
$$

(2) Titie

Replacement. Cross-Site Transfer System Project Specific Quality Assurance P1an for Project W058

CHANGE CONTROL RECORO

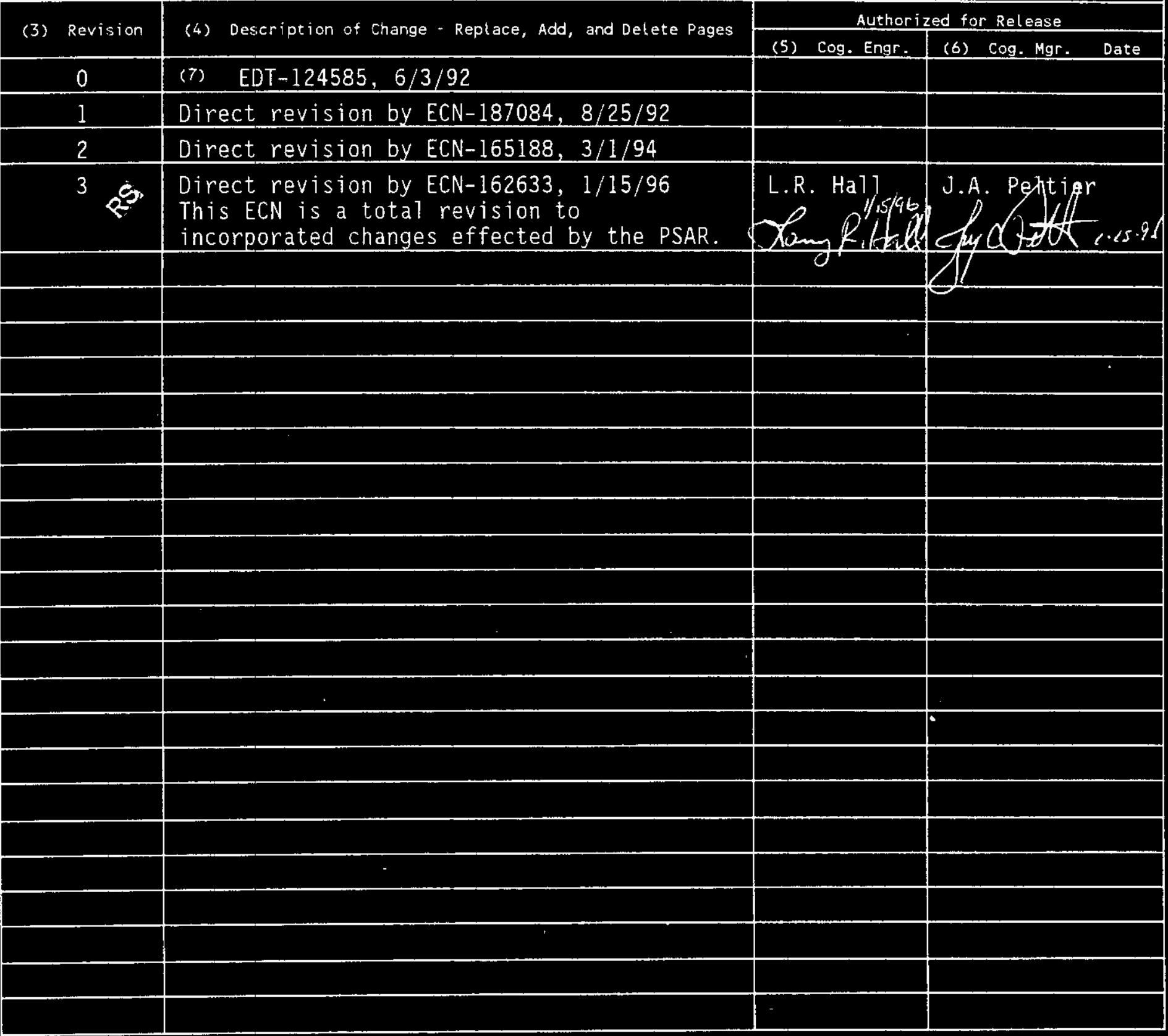


WHC-SD-W058-QAPP-001 REV. 3

PROJECT SPECIFIC QUALITY ASSURANCE PLAN

$W-058$

REPLACEMENT CROSS-SITE TRANSFER SYSTEM

Issued By:

Westinghouse Hanford Company

JANUARY 3, 1996

Prepared By:

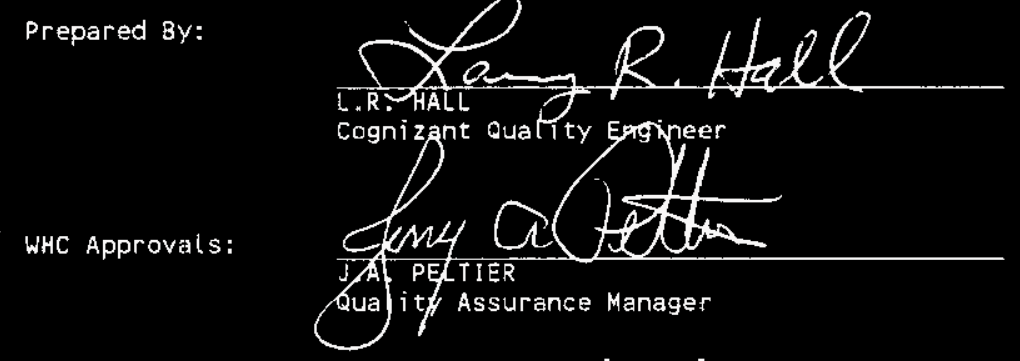

$$
\frac{1}{51 / 15 / 96}
$$

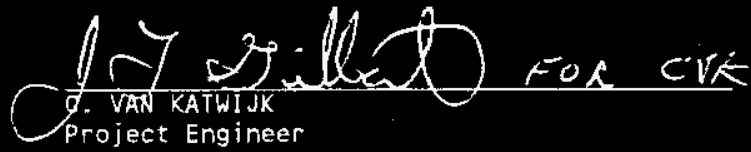

$\frac{1-15-96}{0.06}$
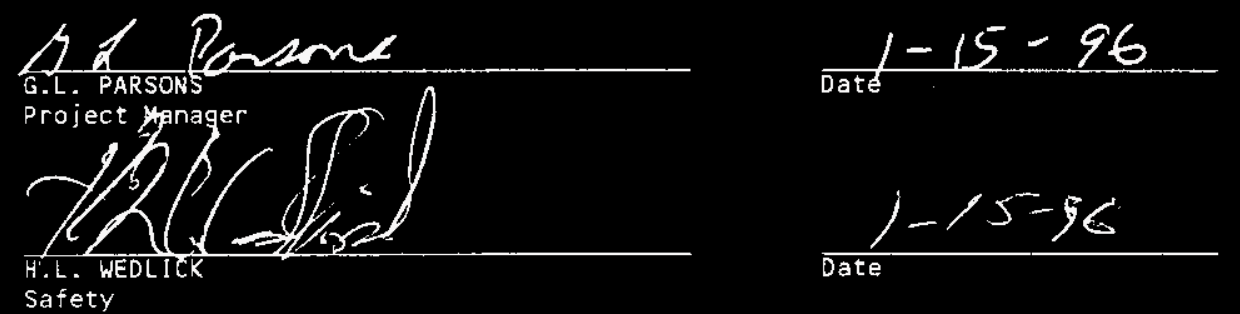

U.S. Department of Energy Approval:

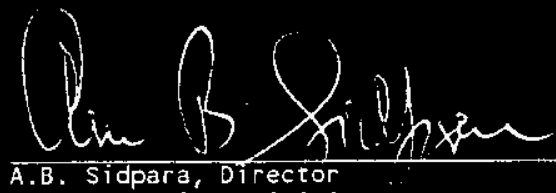

$$
112 x \mid 46
$$

Tank Operations Division

U.S. Department of Energy, Richland Operations Office

1 
WHC-SD-W058-QAPP-001 REV. 3

TABLE OF CONTENTS

$\begin{array}{lr} & \text { Page } \\ \text { PROGRAM DESCRIPTION } & 3 \\ \text { OBJECTIVES } & 5 \\ \text { PROJECT CRITICAL CHARACTERISTICS } & 6 \\ \text { REFERENCES } & 6 \\ \text { FIGURE 1-1 } & 4 \\ \text { ATTACHMENT I } & 7 \\ \text { ATTACHMENT II } & 10\end{array}$




\section{REPLACEMENT CROSS-SITE TRANSFER SYSTEM PROGRAM DESCRIPTION}

This document and the Tank Waste Projects (TWP) Quality Assurance Program Plan (QAPP) WHC-SD-WM-QAPP-018 define the Qual ity Assurance (QA) Program for Project $W-058$. The purpose of this QA program is to control project activities in such a way as to achieve the project mission in a safe and reliable manner. The QA program for the project is implemented through the use of ASME NQA-1, Quality Assurance Program Requirements for Nuclear Facilities (ASME 1994).

This document and the Tank Waste Projects QAPP describe the program and the planned actions which Westinghouse Hanford Company (WHC) will implement to demonstrate and ensure that the project meets the requirements of Title 10 , Code of Federal Regulations, Part 830.120 (10 CFR 830.120), Quality Assurance, through the interpretive guidance of ASME NQA-1.

The Project Participants are responsible for a $Q A$ program covering the quality requirements applicable to their assigned tasks and for work performed by others in support of those tasks. The w058 Project QA program, which controls all participant QA programs, is described in this Replacement CrossSite Transfer System (RCSTS) QAPP and TWP QAPP, and is passed on selectively through the design documents. The W058 Project QA program and the participant QA plans and implementing procedures collectively control the total w058 Project QA program.

The Project organizational relationships are defined in Figure 1-1. Each of the participating organizational responsibilities as shown in Figure 1-1 has an assigned individual responsible for the quality activities described by the Statement of Work (SOW), Contract, Letter of Instruction (LOI), or work order for that participant. The cognizant quality engineer(s) report to management within their respective organizations, ensuring independence from cost and schedule considerations, and providing direct communications channels with appropriate levels of management.

The inspection criteria for system, components and structures identified on the project critical characteristics sheets (Attachment I) are based on the attributes assigned in the Preliminary Safety Analys is Report WHC-SD-W058PSAR-001, safety class designations. Any discrepancies or additional information required of this document regarding safety class designations will be deferred to the PSAR. 


\section{Replacement Cross-Site Transfer System Project Organization}

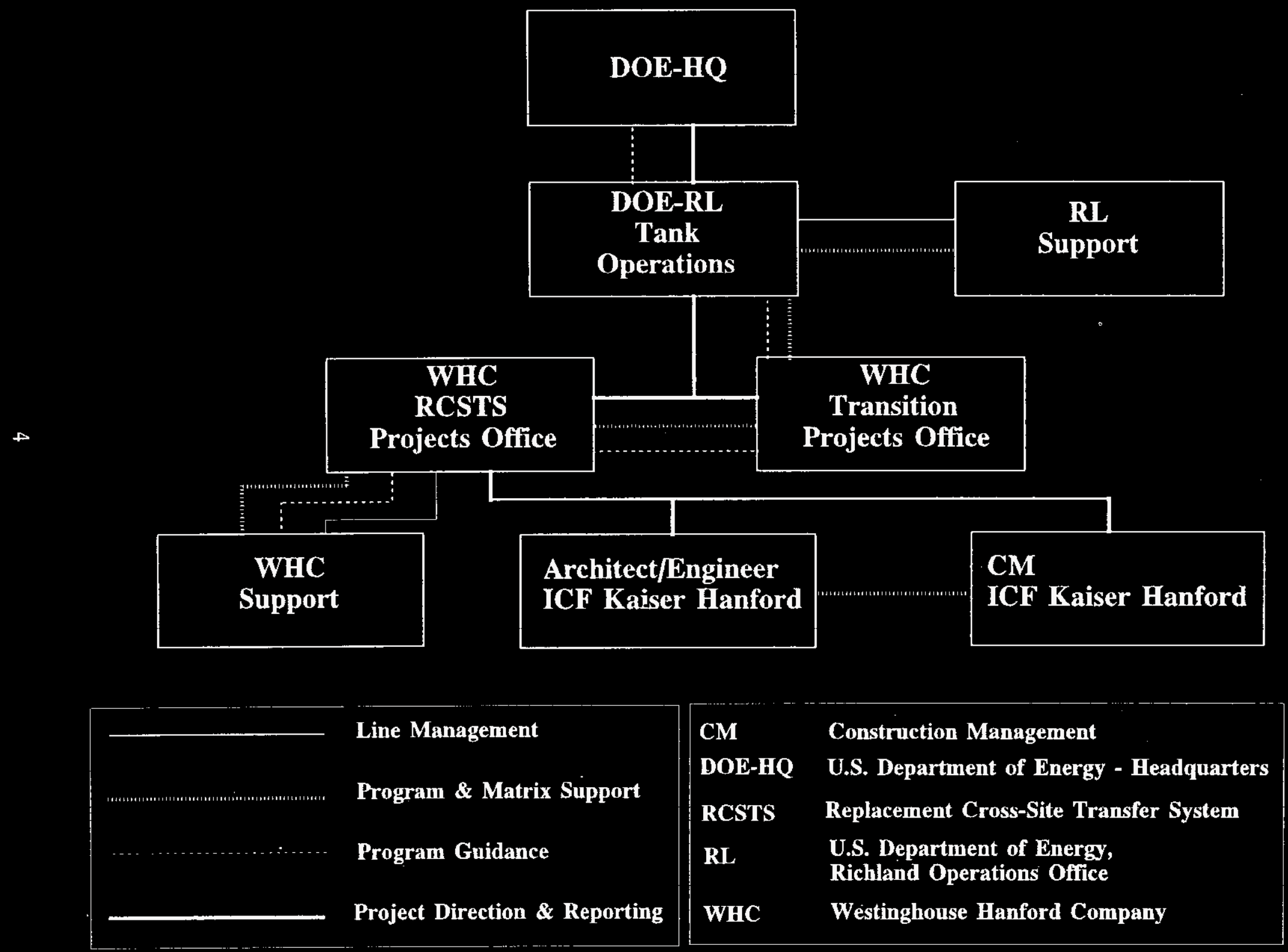




\section{OBJECTIVES}

Radioactive slurry and supernatant waste (mixed liquid waste) has been transferred between the 200 West and 200 East Areas for approximately 40 years. The existing cross-site transfer system configuration is a composite of various projects which have been designed, constructed and operated over the last 40 years. The existing transfer system does not comply with the latest U. S. Department of Energy (DOE) and other Federal and State standards. Certain segments have exceeded, or are nearing the end of their useful 1 ife.

The purpose of Project W058, Replacement Cross-Site Transfer System (RCSTS), is to replace the existing cross-site transfer system. The RCSTS will provide the capability for transferring waste in support of the Hanford Site clean-up mission. This project will provide the necessary upgraded transfer system to support future pretreatment and disposal facilities. The project is required to provide compliant lines, system reliability, and pipeline capacity to meet future waste transfer projections. These transfers will be made from 200 East and 200 West tank farm facilities to the treatment, storage, and disposal facilities in the 200 East Area.

The new system will consist of a pipe-in-pipe connecting the 241-SY A and $B$ valve pits in the 200 West Area with the 244-A Lift Station in the 200 East Area. The scope of work to be accomplished by Project $W-058$ and covered by this Quality Assurance Plan. includes the following:

* Design and construct one diversion box and one vent station.

* Provide the necessary excavation and backfill for diversion box, vent station, and piping.

* Design and provide a booster pump in the diversion box.

* Design and construct a backup system to flush the pipeline from an independent water source to preclude plugging. The system will be capable of supplying water to the suction side of the booster pump.

* Design and provide instrumentation and controls for transfer operation, control, and monitoring.

* Design and construct the new waste transfer lines, encasement, drain and vent lines.

* Design and construct electrical power lines in support of the instrumentation and pumping system. 
REV. 3

\section{PROJECT CRITICAL CHARACTERISTICS}

Safety classifications of systems, components, and structures shall be used as the basis for Quality Assurance Program Requirements (Reference WHCCM-4-46). The project critical characteristics (Attachment I) denote the inspection criteria for systems, components, and/or structures relevant to this project scope, based upon the PSAR.

\section{REFERENCES}

WHC Tank Waste Projects Quality Assurance Program Plan, WHC-SD-WM-QAPP-018.

WHC Functional Design Criteria, (FDC) WHC-SD-W058-FDC-001, Replacement of the Cross-Site Transfer System.

WHC Preliminary Safety Analysis Report, (PSAR), WHC-SD-W058-PSAR-001, for Replacemerit of the Cross-Site Transfer System.

WHC Safety Analysis Manua7, WHC-CM-4-46. 


\section{ATTACHMENT I}

\begin{tabular}{|c|c|c|c|c|c|c|}
\hline \multicolumn{7}{|c|}{ PROJECT CRITICAL CHARACTERISTICS } \\
\hline \multirow{2}{*}{ Item } & \multirow{2}{*}{$\begin{array}{c}\text { Description of Systems, Components, } \\
\text { and Structures }\end{array}$} & \multirow{2}{*}{ Safety** } & \multicolumn{3}{|c|}{$\begin{array}{c}\text { Type of } \\
\text { Inspection* }\end{array}$} & \multirow{2}{*}{ Comments } \\
\hline & & & $\mathbf{F}$ & $G$ & D & \\
\hline 0 & $\begin{array}{l}\text { DIVERSION BOX AND VENT } \\
\text { STATION }\end{array}$ & - & - & - & - & \\
\hline 1. & $\begin{array}{l}\text { Diversion box and vent } \\
\text { station structure }\end{array}$ & $\star \star \star$ & & & $x$ & $\begin{array}{l}\text { Designed to resist a Safety } \\
\text { Class } 1 \text { seismic event and } \\
\text { retain their safety function } \\
\text { of containing spray and pool } \\
\text { leaks. }\end{array}$ \\
\hline 2. & Pit leak detector & $\star \star$ & & & $x$ & $\begin{array}{l}\text { Detection of a leak is } \\
\text { required to result in the } \\
\text { shutdown of the transfer and } \\
\text { booster pumps. }\end{array}$ \\
\hline 3. & Pit entry door & $\star \star *$ & & & $x$ & $\begin{array}{l}\text { Air confinement such that } \\
\text { approximately } 90 \% \text { of the air } \\
\text { passing out of the pit } \\
\text { preferentially goes through } \\
\text { the inlet air HEPA filter when } \\
\text { the door is closed and } \\
\text { penetrations are sealed. }\end{array}$ \\
\hline 4. & $\begin{array}{l}\text { Inlet air HEPA filter } \\
\text { system }\end{array}$ & $\star \star \star$ & & & $x$ & $\begin{array}{l}\text { This is all of the components } \\
\text { of the inlet air HEPA filter } \\
\text { system, including the filter, } \\
\text { nousing, and piping. }\end{array}$ \\
\hline 5. & Emergency pumpout line & ** & & & $x$ & $\begin{array}{l}\text { Line shall be sealed before a } \\
\text { transfer. }\end{array}$ \\
\hline 6. & Air sample 1 ine & $* *$ & & & $X$ & $\begin{array}{l}\text { Line shall be sealed before a } \\
\text { transfer. }\end{array}$ \\
\hline 7. & Exhauster hookup & ** & & & $x$ & $\begin{array}{l}\text { Line shall be sealed before a } \\
\text { transfer. Provides the S.C. } 3 \\
\text { function of mitigating } \\
\text { airborne exposure to } \\
\text { maintenance workers }\end{array}$ \\
\hline 8. & Liner washdown system & $\star \star$ & & & $X$ & $\begin{array}{l}\text { Line shall be sealed before a } \\
\text { transfer. Provides the S.C. } 3 \\
\text { function of mitigating } \\
\text { exposure to maintenance } \\
\text { workers. }\end{array}$ \\
\hline 9. & Shield floor & $* \star$ & & $x$ & & $\begin{array}{l}\text { Provides shielding protection } \\
\text { for facility workers }\end{array}$ \\
\hline
\end{tabular}




\begin{tabular}{|c|c|c|c|c|c|c|}
\hline \multicolumn{7}{|c|}{ PROJECT CRITICAL CHARACTERISTICS } \\
\hline \multirow[t]{2}{*}{ I tem } & \multirow{2}{*}{$\begin{array}{c}\text { Description of Systems, Components, } \\
\text { and structures }\end{array}$} & \multirow{2}{*}{ Safety** } & \multicolumn{3}{|c|}{$\begin{array}{c}\text { Type of } \\
\text { Inspection }\end{array}$} & \multirow{2}{*}{ Comments } \\
\hline & & & $\mathrm{F}$ & G & D & \\
\hline 10. & Pit access corridor & $\star \star$ & & $x$ & $x$ & $\begin{array}{l}\text { Must be designed to withstand } \\
\text { a } S . C .1 \text { seismic event but will } \\
\text { otherwise meet S.C.3 } \\
\text { requirements. }\end{array}$ \\
\hline 11. & $\begin{array}{l}\text { Primary piping/valves } \\
\text { within the pit }\end{array}$ & $\star \star$ & & $x$ & $x$ & $\begin{array}{l}\text { The pit primary piping will be } \\
\text { designed to withstand a S.C.l } \\
\text { seismic event but will } \\
\text { otherwise meet S.C.3 } \\
\text { requirements. }\end{array}$ \\
\hline 0 & $\begin{array}{l}\text { BURIED WASTE TRANSFER } \\
\text { PIPING SYSTEM } \\
\end{array}$ & - & - & - & - & \\
\hline 1. & $\begin{array}{l}\text { Primary transfer piping } \\
\text { (inner) }\end{array}$ & $\star \star$ & $x$ & & $x$ & $\begin{array}{l}\text { The buried primary and. } \\
\text { encasement piping must be } \\
\text { designed to resist a S.C. } 1 \\
\text { seismic event and retain their } \\
\text { safety function of containing }\end{array}$ \\
\hline 2. & $\begin{array}{l}\text { Secondary piping } \\
\text { (encasement) }\end{array}$ & $\star *$ & $x$ & & $x$ & $\begin{array}{l}\text { the waste. In all other } \\
\text { respects the primary piping } \\
\text { and encasement piping shall } \\
\text { meet S.C. } 2 \text { requirements for } \\
\text { containment of the waste. }\end{array}$ \\
\hline 3. & $\begin{array}{l}\text { Pressure relief valve (at } \\
244-\mathrm{A} 1 \mathrm{ift} \text { station) }\end{array}$ & $\star \star$ & $x$ & & $x$ & $\begin{array}{l}\text { Provided to preclude over- } \\
\text { pressurization of the existing } \\
200 \text { East Area transfer piping } \\
\text { system. }\end{array}$ \\
\hline 4. & $\begin{array}{l}\text { Rupture disk (at 244-A } 1 \text { ift } \\
\text { station) }\end{array}$ & $\star \star$ & & & $x$ & $\begin{array}{l}\text { The rupture disk must burst to } \\
\text { allow the pressure relief } \\
\text { valve to provide its safety } \\
\text { function of maintaining } \\
\text { downstream pressures at } \\
\text { acceptable levels. }\end{array}$ \\
\hline 5. & Annulus leak detection & $\star \star$ & $x$ & $\mathrm{X}$ & & \\
\hline 6. & Excavation Program & $\star \star$ & & & $x$ & $\begin{array}{l}\text { An existing excavation permit } \\
\text { program is in place. Physical } \\
\text { and/or administrative barriers } \\
\text { may be required to prevent the } \\
\text { excavation of the transfer } \\
\text { piping. }\end{array}$ \\
\hline 7. & Encasement rupture disks & $\star \star$ & & & $x$ & $\begin{array}{l}\text { Required to } 1 \text { imit the amount } \\
\text { of waste that can escape } \\
\text { through the encasement to the } \\
\text { environment during the } \\
\text { corrosion accident scenario } \\
\text { discussed in the PSAR. }\end{array}$ \\
\hline
\end{tabular}


REV. 3

\begin{tabular}{|c|c|c|c|c|c|c|}
\hline \multicolumn{7}{|c|}{ PROJECT CRITICAL CHARACTERISTICS } \\
\hline \multirow{2}{*}{ I tem } & \multirow{2}{*}{$\begin{array}{c}\text { Description of Systems, Components, } \\
\text { and structures }\end{array}$} & \multirow[t]{2}{*}{ Safety** } & \multicolumn{3}{|c|}{$\begin{array}{l}\text { Type of } \\
\text { Inspection* }\end{array}$} & \multirow{2}{*}{ Comments } \\
\hline & & & $\mathrm{F}$ & $G$ & D & \\
\hline 0 & BACKUP FLUSH SYSTEM & - & - & - & - & \\
\hline 1. & $\begin{array}{l}\text { Isolation valve(s), } \\
\text { flange(s), etc. }\end{array}$ & $\star \star$ & & & $x$ & $\begin{array}{l}\text { Final design of this system } \\
\text { has not been chosen. } \\
\text { Isolation elements (i.e. } \\
\text { manually operated valves, } \\
\text { pneumatic valves, check } \\
\text { valves, blind flanges) would }\end{array}$ \\
\hline 2 . & $\begin{array}{l}\text { Enclosure(s) for isolation } \\
\text { components }\end{array}$ & $\star \star$ & & & $x$ & $\begin{array}{l}\text { purpose of isolating the waste } \\
\text { system from the flush system. } \\
\text { The enclosure(s) would be } \\
\text { designated S.C.I to prevent a } \\
\text { direct spray from reaching the } \\
\text { environment. }\end{array}$ \\
\hline
\end{tabular}

* See attachment II for the definitions on types of inspections.

** Safety classifications will be identified and be consistent with the requirements of WHC-CM-4-46. Refer to the PSAR for Safety class designations as they relate to major systems, components and structures. 


\section{ATTACHMENT II}

\section{INSPECTION DEFINITIONS}

Iypes of Inspection. Due to the variety of types of contracts and subcontracts and the degree of responsibility assigned to the operating contractors, the architect-engineer, the construction contractors, and individual vendors; specific inspection responsibilities are not be prescribed in this plan (specifics will be defined within the construction and procurement specifications). In general, inspection activities are divided into three types: functional, general, and detailed.

1. Functional Inspection (F). Performed to determine overall compliance with contract drawings and specifications. Functional Inspection may vary from inspection of minor items to extensive testing of operating equipment (which must be provided for in contract). It may also serve in making initial determination of the adequacy of the design effort. The field element and the operating contractor participate in functional inspections from the viewpoints of owner and user.

2. General Inspection (G). The fundamental and comprehensive inspection to ascertain that workmanship and the kind and quality of materials conform to the contract specifications.

3. Detailed Inspection (D). Includes, but is not limited to, verification of details, such as checking location and size of reinforcing bars, maintaining records of concrete batch plant operations, verifying the use of proper welding rods, checking riveting and welding, and performing other inspection for quality assurance purposes. 
DISTRIBUTION SHEET

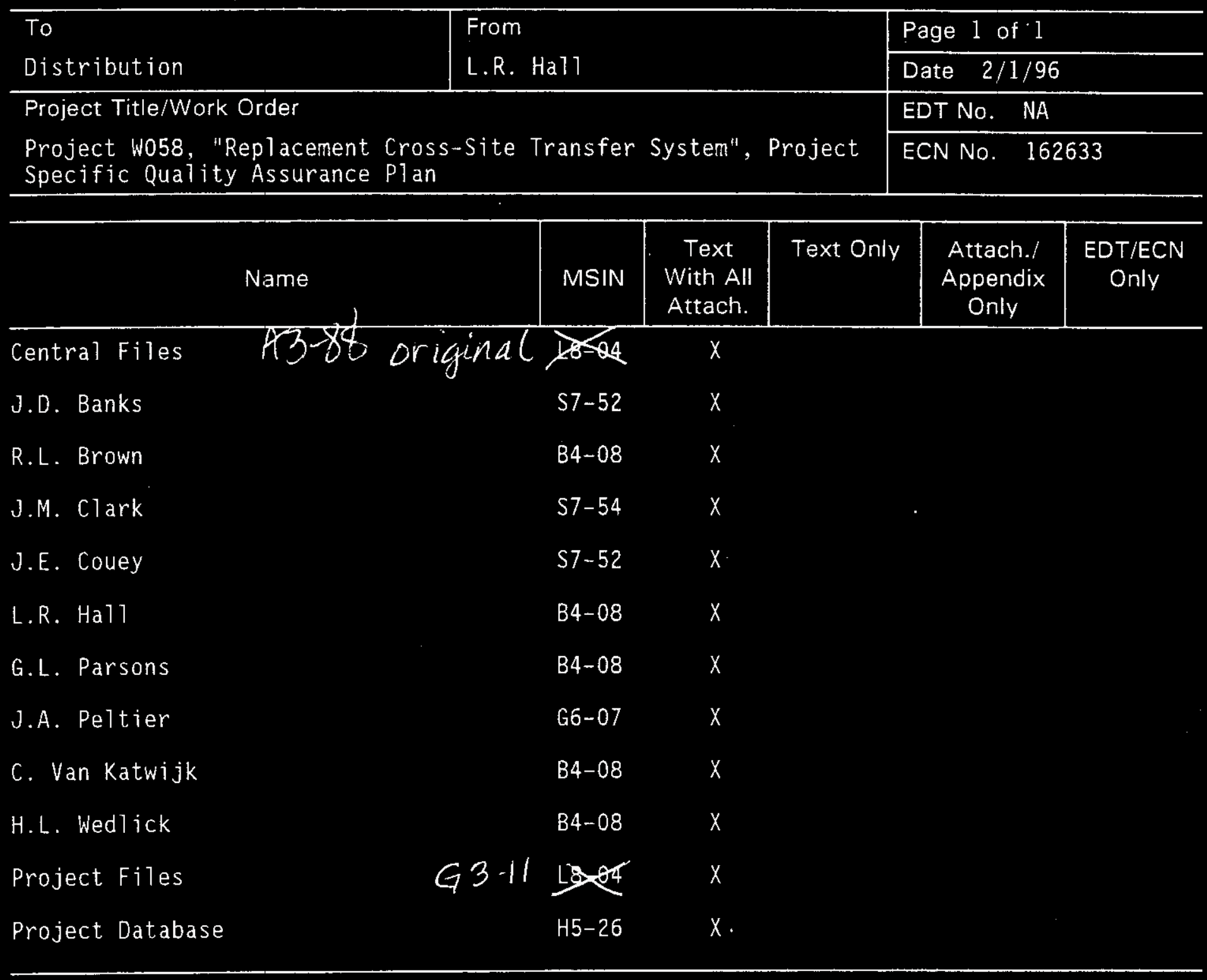

